\title{
A Failure Modes, Mechanisms, and Effects Analysis (FMMEA) of
} Lithium-ion Batteries

\author{
Christopher Hendricks ${ }^{\mathrm{a}}$, Nick Williard ${ }^{\mathrm{a}}$, Sony Mathew ${ }^{\mathrm{a}}$, and Michael Pecht ${ }^{1, \mathrm{a}}$ \\ Center for Advanced Life Cycle Engineering (CALCE) \\ University of Maryland \\ College Park, MD, USA
}

1- Corresponding author. Tel.: +1 301405 5323; fax: +1 301314 9269; e-mail: pecht@ calce.umd.edu

a - Center for Advanced Life Cycle Engineering, University of Maryland, Room 1103, Building 89, College Park, MD 20742, USA; e-mail: chendri1@calce.umd.edu; nwilliar@calce.umd.edu; sonym@calce.umd.edu; pecht@calce.umd.edu

Keywords: Lithium-ion battery; Failure modes, mechanisms, and effects analysis; Physics-offailure; Battery reliability; 


\section{Introduction}

Lithium-ion battery technology was first commercialized in 1991, and is successful due to its high energy density, high operating voltage, and low self-discharge rate. Applications of lithium-ion batteries range from portable consumer electronics to aerospace and electric vehicles (EVs). The fundamental structure of a lithium-ion cell is shown in Figure 1. A lithium-ion battery consists of this cell-sandwich structure packaged in several different form factors such as cylindrical, coin, pouch, and prismatic. The anode of most commercial cells consists of a carbonaceous material, usually graphite, adhered to a copper current collector with a polyvinylidene fluoride (PVDF) binder. The cathode is usually a metal oxide material adhered to an aluminum current collector with a PVDF binder and an electronically conductive carbon additive. The electrodes are separated by a polymer sheet that allows ion transport but prevents the two electrodes from electrically shorting. Finally, the cell is permeated by an electrolyte composed of a lithium salt dissolved in an organic solvent to facilitate ion transport.

Lithium-ion batteries are also known as "rocking-chair" batteries, as they operate based on a reversible insertion principle called intercalation. During charge or discharge, lithium ions are shuttled between the two electrodes where they are accommodated in the electrode's lattice. This charging and discharging process can be repeated many times; however, the maximum amount of electrical charge that a battery can store and deliver decreases over time. This capacity fade phenomenon is the result of various degradation mechanisms within the battery, such as chemical side reactions or loss of conductivity $[1,2]$. On the other hand, lithium-ion batteries also experience catastrophic failures that can occur suddenly. Catastrophic failures often result in venting of the electrolyte, fire, or explosion. This is usually due to an overstress condition where the battery is abused or operated outside of its recommended voltage, current, or temperature limits [3-5]. 
Lithium-ion batteries require continuous monitoring and control to prevent premature performance degradation and catastrophic failures. Without proper control over the operating conditions of a battery system, the system is susceptible to failures resulting in explosion, fire, expulsion of toxic gasses, or other negative impacts to humans and the environment. In May 2012, in Shenzhen, China, an electric taxi made by BYD was struck by another vehicle, causing a fire and explosion. This resulted in a 5\% drop in BYD shares, even before the root cause of the fire was released [6]. Following an investigation by the Chinese government, it was found that short-circuiting of high-voltage power lines initiated the fire that spread to about $25 \%$ of the batteries in the pack [7]. Although the battery was not directly responsible in this case, EV failures resulting in fire receive negative press coverage and have damaging financial impacts.

In May 2012, the U.S. Postal Service placed a ban on the international shipping of products with lithium-ion batteries due to fears of short circuits causing fires in the cargo compartments of airplanes [8]. In January 2013, two separate lithium-ion battery incidents on Boeing 787 Dreamliners resulted in the grounding of the entire fleet $[9,10]$. A 787 battery incident at Logan International Airport in Boston, Massachusetts, resulted in a fire that was traced to a lithium-ion battery that served as a backup to the onboard power system. Safety concerns regarding lithium-ion batteries have persisted, particularly as the technology has been scaled up to larger, safety-critical applications such as EVs and aerospace applications.

A battery management system (BMS) employs physical and chemical safety mechanisms and control-based strategies to mitigate failure [11-14]. Knowledge of all underlying causes and mechanisms that lead to catastrophic failure can assist in the design of new safety mechanisms and advanced control techniques that detect and prevent the onset of battery fires and explosions. Because a battery can take many different paths towards failure, a methodology to illustrate all possible causes of failure is required. In this paper, a comprehensive failure modes, mechanisms, and effects analysis (FMMEA) methodology is applied to lithium-ion batteries. The FMMEA highlights the potential failure mechanisms, root causes and failure modes, the likelihood of 
occurrence, severity and detection of the associated failure mechanisms, and the models that capture the effects of various environmental stresses on battery lifetime. In the following subsections, each of the components of a lithium-ion battery are analyzed and evaluated as per FMMEA methodology.

\section{Failure Modes, Mechanisms, and Effects Analysis (FMMEA)}

FMMEA is "a systematic methodology to identify potential failure mechanisms and models for all potential failure modes, and to prioritize failure mechanisms" [15] and is the cornerstone of the physics-of-failure (PoF) approach to reliability assessment of systems, subsystems, and components. FMMEA differs from traditional FMEA as it considers failure mechanisms and their relevance in assessing the potential risks to the system. Failure mechanisms are identified as the "processes by which physical, electrical, chemical, and mechanical stresses induce failures" [16]. These mechanisms describe the fundamental manner in which a device or component can fail. Failure modes, on the other hand, are defined as the manner by which a failure is physically observed. The mode may not be easily observed in-situ; however, a complete failure analysis would reveal the source of the failure. The failure cause is the driving force behind the failure mechanism, and can be the result of either internal or external stresses. Finally, the failure effect is how the failure mechanism impacts the usability of the device or component.

A detailed FMMEA process is covered in [15]. FMMEA is derived from the wellestablished failure mode and effects analysis (FMEA), which was developed to identify and classify failures with a focus on mission success and safety [17]. A survey of close to 500 reliability experts found that FMEA is the most important task in a reliability analysis because of the potential to prevent failure through a detailed failure analysis [18]. FMEA describes the modes and effects but does not identify the physical mechanisms that lead to failure. The failure mechanisms are critical in assessing the role that the environment plays in accelerating failure, 
and this enables modeling of the interactions between life cycle environmental loads and time-tofailure (TTF). Therefore, FMMEA can assist in the PoF approach to reliability by prioritizing failure mechanisms based on their risk. Furthermore, physics-based models can be used in a prognostics and health management (PHM) framework to predict the remaining useful performance (RUP) of a device [19, 20].

\subsection{Development of FMMEA for Lithium-ion Batteries}

Using the steps outlined in [15], a general FMMEA for commercially available lithiumion batteries was developed on the individual cell level. The FMMEA is shown in Table 1, and it provides a comprehensive list of the parts within a lithium-ion battery that can fail or degrade, the mode by which the failure is observed, the potential causes of the failure, whether the failure is brought on by progressive degradation (wearout) or abrupt overstress, the frequency of occurrence, the severity of failure, and the ease of detection of the failure mechanism. This FMMEA was developed based on experience gained from years of reliability testing, battery disassembly, and failure analysis [21]. Sections 2.1.1-2.1.6 expands on the FMMEA table and how it was derived, along with an introduction to physics-based models that attempt to capture the individual failure mechanisms. Section 2.2 discusses how risk prioritization of the failure mechanisms is performed, and how this can lead to improved models and BMSs.

\subsubsection{Anode Active Material}

The failure mechanisms described in this paper for the anode are based on the commonly used carbon-based materials. While research is ongoing for new anode materials such as silicon or tin, non-carbon anodes are not widely used due to large volumetric changes during lithium insertion [22]. Loss of capacity in the battery is partially due to the reactivity between graphite 
and the organic solvents. Graphite readily reacts with the organic solvents used in lithium-ion battery electrolytes, such as ethylene carbonate (EC) or dimethyl carbonate (DMC) [23, 24]. When a battery is first assembled, side-reactions between the solvents and the anode result in the formation of a solid electrolyte interphase (SEI) layer on the surface of the graphite particles and irreversible capacity loss during the formation period [23-26]. This layer is permeable to lithium ions and helps prevent further side reactions with the graphite that would further reduce the useable capacity of the battery. However, as the battery is cycled, new reaction sites become available due to electrode expansion and contraction, resulting in a wearout failure mechanism that continually reduces the capacity of the battery. The failure mechanism in this case is a chemical reduction reaction at the electrode, and it is physically observed through the thickening of the solid electrolyte interface (SEI) layer. Research into the composition and morphology of the SEI layer has provided insights into the capacity and power fade of lithium-ion batteries. Due to the fragile nature of the SEI layer, researchers have attempted to perform studies with minimal cell disassembly. Neutron magnetic resonance (NMR) imaging of lithium-ion batteries has been performed on lithium-ion batteries with graphite anodes to elucidate the SEI growth mechanism [27-29]. If cell disassembly is performed, the procedure needs to take place in a glove box purged with an inert gas (often argon) with a low water vapor and oxygen environment ( $<5 \mathrm{ppm}$ of each) [21]. Once the cell is disassembled, researchers have utilized analytical techniques including time-of-flight secondary ion mass spectometry (TOF-SIMS) [30], scanning electron microscopy (SEM) [30, 31], transmission electron microscopy (TEM) [32], X-ray photoelectron spectroscopy (XPS) [30, 33, 34, 38], X-ray absorption spectroscopy (XAS) [35], atomic force microscopy (AFM) [38], Fourier transform infrared (FTIR) spectroscopy [34, 36], and Raman spectroscopy [37] to study the thickness, morphology, and composition of the SEI layer. Despite the numerous measurement techniques, additional research into the SEI layer is necessary, especially if a realistic SEI growth model is desired. The difficulty in SEI layer characterization is due to the 
fact that the SEI layer is fragile, readily reacts with the environment if it is not properly protected, and consists of a wide variety of organic and inorganic species.

SEI layer growth is typically modeled as a parasitic side reaction [40-42] where a TTF or time-to-capacity reduction is obtained as a function of reaction kinetics, mass transport, and cell geometry. An assumption is often made that the SEI layer is wholly responsible for the capacity and power fade, often neglecting concurrent failure mechanisms. While the SEI layer does not directly lead to catastrophic failure, it can decompose at elevated temperatures [3, 23], and could contribute to a thermal runaway event by releasing gas. In this FMMEA, the formation and growth of the SEI layer is seen as a wearout failure that leads to a reduction in battery capacity and increased resistance.

If the battery is charged rapidly or at low temperatures, lithium metal can deposit on the surface of the anode [43-45]. Over time, these deposits can develop into dendritic structures that may puncture the separator and initiate internal short circuits. This situation can lead directly to catastrophic failure and is often difficult to detect until a short circuit actually occurs. Several studies [46-52] have identified models for predicting lithium plating as a relationship between dendrite tip velocity and the applied current density and diffusion characteristics of the lithium. Experimental validation of lithium growth in full electrochemical cells is difficult to observe, and the models are limited to predicting the growth of individual dendrites. Specialized cells with quartz glass windows have been developed to observe dendrite growth in-situ [53], but observation of lithium dendritic structures in commercial cells is not possible. NMR has been performed to detect metallic dendrites in lithium-ion cells [54]. Cell disassembly can also be performed, but the reactivity of the lithium dendrites complicates the process. Zier et al. suggested dyeing the electrode structure to elucidate the location of dendritic structures [55] by creating a greater contrast in electron microscopy images. If dendrite formation occurs, but causes an internal short circuit prior to disassembly, detection may be even more difficult. The lithium dendrites can vaporize due to surge currents, eliminating traces of their presence. Localized 
melting of the separator can indicate possible dendrite formation, but it could also be a result of local heating or metallic contamination. There are many opportunities to further develop models that predict not only the onset of lithium plating, but the time-to-failure under a number of operating conditions.

Electrode particle fracture can also occur if the battery is charged too quickly or if the electrode particle size distribution is not well designed. Typically, sub-micron-sized electrode particles have reduced internal intercalation-induced stresses, allowing the battery's life to be prolonged $[56,57]$. Particle fracture can be observed as microcracks on the electrode particle surface as a result of crack initiation and propagation during repeated lithium intercalation and deintercalation. The exposed particle surface will then form a fresh SEI layer, which can be investigated with a variety of analytical techniques described above. After the cell is disassembled, the electrode can be observed using SEM to locate fractured particles. Much work has been performed in optimizing the design of battery electrodes through an understanding of the stress generation during lithium-ion intercalation. Christensen and Newman [58, 59] developed the initial framework for the modeling of intercalation stresses, and other researchers have continued to expand their work for other materials and electrode geometries [56, 57, 60-62]. While modeling of particle stresses has helped in the design of battery electrodes to minimize mechanical stresses, the effect of particle fracture on the TTF of a lithium-ion battery has not been discussed in the literature. The role of particle fracture in capacity loss and power fade needs to be further elucidated to implement accurate lifetime prediction models based on a particle fracture failure mechanism.

Volumetric changes to the electrode structure can also lead to electronic disconnect in the battery, whereby parts of the electrode become unusable. The lithium intercalation reaction occurs when an electron and lithium ion combine in the graphite particles. Because the electrolyte is electronically insulated, a conductive network of particles is required to facilitate electron transport through the electrode structure. Volumetric changes associated with repeated 
intercalation can cause isolation of electrode particles, resulting in a reduction in usable capacity. This change in electrode structure can be observed by measuring the porosity and tortuosity of the electrode structure. This process is typically performed by milling away the electrode surface using focused ion beam (FIB) and measuring a cross-section of the electrode using SEM [63, 64] or employing high resolution X-Ray tomography [65].

\subsubsection{Cathode Active Material}

The cathode usually consists of a metal oxide, such as lithium cobalt oxide $\left(\mathrm{LiCoO}_{2}\right)$ or lithium manganese dioxide $\left(\mathrm{LiMn}_{2} \mathrm{O}_{4}\right)$ [66]. Lithium iron phosphate $\left(\mathrm{LiFePO}_{4}\right)$ is another cathode material that is popular for high-rate applications $[66,67]$. The cathode also operates on an insertion principle, and mechanical stress and degradation can contribute to the fracture of particles and reduction in battery capacity as described for the anode. The cathode is affected by the growth of an SEI layer, but to a lesser extent than the graphite due to the high voltage (i.e., greater than $4.5 \mathrm{~V}$ ) required to grow a stable film $[68,69]$. The cathode is also susceptible to thermally driven decomposition, particularly if the cell is overcharged. Under overcharge conditions, the electrolyte becomes unstable [3, 70], which leads to reactions between the electrolyte and cathode that can raise the cell's temperature and release oxygen gas [71]. If this process escalates, catastrophic failure is possible. Overcharging of the cathode structure can be observed by either measuring the gas species evolved via gas chromatography and mass spectrometry [71] or through diffraction-based studies of the electrode structure [72]. However, no models have been developed that can predict gas evolution within the cell as a result of overcharge reactions.

\subsubsection{Current Collectors}


The anode active material is coated onto a copper current collector that is largely unaffected by the operation of the battery. However, the copper can dissolve if the battery is overdischarged [24, 73-77]. Copper dissolution can lead to free copper particles suspended in the electrolyte. If enough copper dissolves, the possibility of an internal short circuit becomes greater. While overdischarge can be largely avoided through proper battery management, it is still possible in the event of BMS failure, misuse of the battery, or self-discharge during long periods of storage. Copper content on the electrode surfaces, in the electrolyte, or on the separator can be observed through energy dispersive spectroscopy (EDS) [74] or XPS; however, the relationship between the quantity of copper and the likelihood of short circuit has not been suitably quantified. Additionally, it is possible to study the bare copper current collector for loss of material through optical microscopy followed by SEM or AFM. Alternately, the cathode active material is coated onto an aluminum current collector. If the cell is overcharged, the aluminum can corrode $[78,79]$. This can lead to a reduction of power or increased resistance. While aluminum pitting corrosion is not a catastrophic failure, overcharge also causes electrode decomposition. The effect of metallic dissolution has not been modeled and related to a TTF. Catastrophic failure due to free particles of copper in the electrolyte is not deterministic and may not be directly predictable. Focus should be placed on ensuring that batteries are never overcharged or overdischarged, and strategies to detect transient short circuits that could be a result of metallic contamination should be developed.

\subsubsection{Separator}

The separator in a lithium-ion battery is a porous polymer sheet that allows ion transport while preventing internal electrical short circuits between the electrodes. If the integrity of the separator is compromised, the electrodes can make contact, resulting in an internal short circuit that can cause heat generation and potentially lead to full thermal runaway [80]. Typically, 
electrode contact is due to thermal or mechanical damage to the separator. If metallic particles are present in the battery and puncture the separator, internal short-circuiting can occur. These particles can come from external contamination during assembly, lithium dendrite growth, and/or copper dissolution. Internal short-circuit failure mechanisms are observed as an anode/cathode bridge by the particle accompanied by tearing of the separator. Thermal and mechanical damage to the separator can be observed through an SEM. Additionally, melted separator can be seen optically during a cell disassembly procedure and provide some insight into the initiation point of the failure. Researchers have begun investigating the stresses generated in the separator as a result of battery operation and abuse [52, 81-84]. Excessive heating of the polymer past its melting point can result in an inoperable battery or in a catastrophic thermal runaway. As a safety mechanism, the pores of the separator are designed to close to prevent short-circuiting [80, 82]. However, if the battery continues to heat up, the separator could further melt and allow an internal short circuit $[80,82]$. Finally, the separator is usually wider than the electrodes to prevent short-circuiting at the edges. However, separator shrinkage when exposed to electrolyte or high temperatures could cause the electrode edges to touch, possibly initiating a thermal runaway [80, 83]. Proper design and selection of the separator can aid in preventing thermal runaway, but proper manufacturing and screening procedures are required to prevent contaminated cells from entering the supply chain.

\subsubsection{Electrolyte}

An organic solvent and a lithium salt make up the electrolyte of the battery. The electrolyte helps facilitate lithium-ion transport while inhibiting electron transport between the anode and the cathode. The most commonly used solvents are organic-based carbonates, such as EC and DMC [70, 87]. The electrolyte can contribute to side reactions with the electrodes that reduce the available capacity of the battery and lead to wearout failure. While the electrolyte most 
commonly used in lithium-ion batteries has beneficial properties for ion transport, it is highly flammable and unstable outside of a narrow voltage and temperature window. If operated under extreme temperature or voltage conditions, the electrolyte can decompose, cause gas generation, and lead to thermal runaway [70]. Typically, electrolyte decomposition occurs at temperatures above $200{ }^{\circ} \mathrm{C}$, at which point thermal runaway becomes likely [3]. The electrolyte can be analyzed and compared to virgin electrolyte to identify the degradation and decomposition mechanisms occurring within the cell or the electrodes can be studied as previously described to observe decomposition products. Previous studies have utilized NMR [85], FTIR [86], thermogravimetric analysis (TGA) [86], differential scanning calorimetry (DSC) [88], and accelerated rate calorimetry (ARC) [89] to measure electrolyte properties and identify degradation and decomposition pathways for the popular lithium-ion battery solvents. Alternately, researchers have focused on heat generation and heat dissipation rates [90-92] when modeling thermal abuse that would lead to electrolyte decomposition. Thermal abuse models evaluate the contributions of different sources of heat generation, including short circuits and chemical reactions, to identify a timeline for the initiation of thermal runaway. These models have applications in developing thermal management systems and anomaly detection; however, large-format batteries do not always have a uniform temperature distribution on the surface of the cell. By the time the rise in temperature is detected, it may be difficult to prevent thermal runaway. In addition to developing new methods to detect the internal temperature of the cell, it is important to focus on the root causes of temperature generation and develop models to predict the onset of an internal short circuit or dendrite growth.

\subsubsection{Cell Terminals and Casing}

The cell terminals are responsible for conducting current from the current collectors to the external electric circuit. The terminals are typically connected to the current collectors by spot 
welding a tab onto the current collector. Poor-quality spot welds or an insufficient number of spot welds could lead to increased resistance to electrical current. Quality control issues with spot welding can be identified visually through optical microscopy, or mechanically through a pull or shear test. Additionally, thermo-mechanical fatigue can cause the connection between the cell terminals and the current collector to degrade and fail. Loss of connectivity or intermittent connectivity could cause the host device to malfunction or fail altogether. Moisture surrounding the terminals on the exterior of the battery can cause short-circuiting of the cell through corrosion reactions or through formed conductive pathways. In the investigation surrounding the Chevy Volt fire in June 2011, the battery fire was traced back to coolant leakage following a side-impact crash test [93]. The coolant was electrically conductive at high voltages, causing an external short circuit between the battery's terminals. The short circuit generated enough heat for the batteries to undergo thermal runaway. Alternately, moisture can cause corrosion between the battery's terminals, resulting in a slow discharge of the battery or excessive heat generation, and can be modeled using a variety of well-developed models for electronics corrosion [94-97]. The battery can be left inoperable, or excessive heat generation could lead to thermal runaway. Therefore, it is important to not only protect the battery from moisture, but also to predict the risk of corrosion formation under a variety of operating conditions.

Another way that thermal runaway could be induced is through denting or crushing of the cell casing, which causes stress to be transferred to the electrodes and possibly results in a short circuit. Finite element modeling has been performed by $[98,99]$ to help develop better designed battery packs and predict the onset of catastrophic failure due to mechanical abuse. Simplified analytical models are needed for real-time assessment of mechanical damage to the cell. In the case of an EV accident, first responders need to know the risk of thermal runaway. A full-scale finite element model will not be appropriate for this type of control scenario, therefore, additional investigation into new ways to detect and model battery damage under mechanical loads is required. 


\subsection{Risk Prioritization}

As seen in Table 1, any of the battery components can cause failure of the entire battery. Some failures are less severe and unavoidable, such as progressive capacity degradation, while other failures are disastrous and require mitigation strategies. One way to determine which failures to focus on is to rank the failure mechanisms based on their likelihood of occurrence, severity of occurrence, and ease of detection. These mechanisms can be ranked by assigning scores for each of these three considerations and combining the results into an overall risk prioritization number (RPN). The RPN is the product of the severity rating, the occurrence rating, and the ease of detection [20]. The final prioritization step involves classification of the failure mechanisms into risk levels based on the RPN. For example, a failure mechanism that has high likelihood of occurrence, high severity, and is not easy to detect would be ranked above all other failure mechanisms; however, if a failure mechanism is easy to detect, it would not be ranked as high as other failure mechanisms. The scale for classifying the likelihood, severity, and ease of detection varies with the level of expertise of the FMMEA team and the level of detail to which data can be obtained for the system. Additionally, the calculated RPN value is dependent on the application and the expected use conditions. As a result, the same battery can be used in a laptop computer and an EV, but the risk prioritization can be completely different.

\section{Conclusions}

Lithium-ion batteries are complex systems that undergo many different degradation mechanisms, each of which individually and in combination can lead to performance degradation, failure and safety issues. As a result, it is necessary to identify the ways a battery can degrade and assess the risk of each type of degradation process and failure mechanism. 
This paper identifies the degradation and failure mechanisms of Lithium-ion batteries and the models that can relate applied stresses and use conditions to a time to failure (TTF). Lithiumion batteries undergo complex life cycles as a result of their use in applications ranging from electric vehicles and autonomous unmanned vehicles to satellites and aircraft. The development of a FMMEA is the first step in making a transition from empirical to physics-based lithium-ion battery failure models to account for the stresses experienced by lithium-ion batteries during their life cycle. The FMMEA's most important contribution is the identification and organization of failure mechanisms and the models that can predict the onset of degradation or failure.

As a result of the development of the lithium-ion battery FMMEA in this paper, improvements in battery failure mitigation can be developed and implemented. FMMEAenhanced design and simulation tools can enable battery manufacturers to rapidly develop new batteries by assessing the impact of chemistry and design on performance and safety. Battery system designers will also benefit from life cycle simulation capabilities that include models for all relevant failure mechanisms. Accounting for the impact of expected use conditions on battery longevity can be used to design advanced battery management systems that employ optimal charging strategies and allow for condition based maintenance as a result of accurate state of health estimation. Additionally, thermal management and failure mitigation strategies can be improved through a physics-based understanding of battery failure. Standards organizations and industry groups can design better qualification and safety tests based on the findings of an FMMEA to assess not only the effect of a given application's life cycle stresses on the battery, but to also capture the interactions between different failure mechanisms that exacerbate failure. Traditional battery reliability and safety testing relies on standards such as IEEE 1625/1725, IEC 61960, UL 1642, and UN 38.3; however, the tests typically rely on pass/fail criteria that do not provide information that can be used in system design and risk assessment. 
As a result of the FMMEA process, it is possible to quantify the impact of performance or abuse tests on the safety of a battery or battery system. Outputs of safety tests such as heat generation rates and gas generation can serve as inputs for battery models that predict the response of a system to environmental stresses. Through the use of physics-based modeling informed by a FMMEA, the costs of testing can be reduced while enhancing system safety. Performing the correct tests for a given application and its associated life-cycle stresses and utilizing cell-level outputs to simulate pack-level responses can minimize the time and cost of performance and abuse testing. Lithium-ion batteries are an enabling technology for a wide array of applications, but concerns persist due to the volatile nature of their components. Improved design and testing influenced by a FMMEA can lead to safer and more reliable battery systems.

\section{Acknowledgments}

The authors would like to thank the more than 150 companies and organizations that support research activities at the Center for Advanced Life Cycle Engineering (CALCE) at the University of Maryland annually. The authors would also like to thank the members of the Prognostics and Health Management consortium at CALCE, the National Science Foundation (No. 1234451), and the ARCS Foundation for their support of this work.

\section{References}

1. R. B. Wright, J. P. Christophersen, C. G. Motloch, J. R. Belt, C. D. Ho, V. S. Battaglia, J. A. Barnes, T. Q. Duong, and R. A. Sutula, "Power fade and capacity fade resulting from 
cycle-life testing of advanced technology development program lithium-ion batteries," $J$. Power Sources, 119-121 (2003) 865-869.

2. J. Wang, J. Purewal, P. Liu, J. Hicks-Garner, S. Soukazian, E. Sherman, A. Sorenson, L. $\mathrm{Vu}, \mathrm{H}$. Tataria, and M. W. Verbrugge, "Degradation of lithium ion batteries employing graphite negatives and nickel-cobalt-manganese oxide + spinel manganese oxide positives: Part 1, aging mechanisms and life estimation," J. Power Sources, 269 (2014) 937-948.

3. Q. Wang, P. Ping, X. Zhao, G. Chu, J. Sun, and C. Chen, "Thermal runaway caused fire and explosion of lithium ion battery," J. Power Sources, 208 (2012) 210-224.

4. X. Feng, J. Sun, M. Ouyang, F. Wang, X. He, L. Lu, and H. Peng, "Characterization of penetration induced thermal runaway propagation process within a large format lithium ion battery module," J. Power Sources, 275 (1) (2015) 261-273.

5. F. Larsson and B.-E. Mellander, "Abuse by external heating, overcharge, and short circuiting of commercial lithium-ion battery cells," J. Electrochem. Soc., 161 (10) (2014) A1611-A1617.

6. C. Lee, "BYD shares in China and Hong Kong recover following exploding taxi incident," Gasgoo: Automotive News, 5/31/12. Accessed on 4/4/13 from: http://autonews.gasgoo.com/china-news/byd-shares-in-china-and-hong-kong-recoverfollowin-120531.shtml

7. "Chinese probe clears electric battery in deadly accident," Reuters, 8/3/12. Accessed on 12/6/13 from: http://in.reuters.com/article/2012/08/03/byd-china-probeidINL2E8J33CB20120803

8. T. Conneally, "Sorry, you can't mail your iPhone or iPad overseas 'til next year," betanews, 5/25/12. Accessed on 4/4/13 from: http://betanews.com/2012/05/25/sorryyou-cant-mail-your-iphone-or-ipad-overseas-til-next-year/ 
9. J. Topham and A. Scott, "Boeing Dreamliners grounded worldwide on battery checks," Reuters, $1 / 17 / 13$. Accessed $\quad$ on $4 / 4 / 13$ from: http://www.reuters.com/article/2013/01/17/us-boeing-dreamlineridUSBRE90F1N820130117

10. N. Williard, W. He, C. Hendricks, and M. Pecht, "Lessons learned from the 787 Dreamliner issue on lithium-ion battery reliability," Energies, 6 (2013) 4682-4695.

11. L. Lu, X. Han, J. Li, J. Hua, M. Ouyang, "A review on the key issues for lithium-ion battery management in electric vehicles," J. Power Sources, 226 (15) (2013) 272-288.

12. W. He, N. Williard, C. Chen, and M. Pecht, "State of charge estimation for electric vehicle batteries using unscented Kalman filtering," Microelectron. Reliab., 53 (2013) $840-847$.

13. Y. Xing, E. Ma, K. L. Tsui, and M. Pecht, "Battery management systems in electric and hybrid vehicles," Energies, 4 (2011) 1840-1857.

14. W. He, N. Williard, M. Osterman, and M. Pecht, "Prognostics of lithium-ion batteries based on Dempster-Shafer theory and the Bayesian Monte Carlo method," J. Power Sources, 196 (2011) 10314-10321.

15. S. Ganesan, V. Eveloy, D. Das, and M. Pecht, "Identification and utilization of failure mechanisms to enhance FMEA and FMECA," Proc. IEEE Workshop Accel. Stress Test. Reliab. (ASTR), Austin, TX, Oct 3-5 (2005).

16. J. Hu, D. Barke, A. Dasgupta, and A. Arora, "Role of failure-mechanism identification in accelerated testing," J. IES, 36 (4) (1993) 39-45.

17. C. S. Carlson (2012). Effective FMEAs: Achieving Safe, Reliable, and Economical Products and Processes using Failure Mode and Effects Analysis. Hoboken, NJ: Wiley \& Sons.

18. C. Carlson, G. Sarakakis, D. Groebel, and A. Mettas, "Best practices for effective reliability program plans," Reliab. Maintainab. Symp., Jan. 25-28, 2010, pp. 1-7. 
19. S. Cheng, M. Azarian, and M. Pecht, "Sensor systems for prognostics and health management," Sensors, 10 (2010) 5774-5797.

20. S. Mathew, M. Alam, and M. Pecht, "Identification of failure mechanisms to enhance prognostic outcomes," J. Fail. Anal. Prev., 12 (2012) 66-73.

21. N. Williard, B. Sood, M. Osterman, and M. Pecht, "Disassembly methodology for conducting failure analysis on lithium-ion batteries," J. Mater. Sci.: Mater. Electron., 22 (2011) 1616-1630.

22. W.-J. Zhang, "A review of the electrochemical performance of alloy anodes for lithiumion batteries," J. Power Sources, 196 (1) (2011) 13-24.

23. V. A. Agubra and J. W. Fergus, "The formation and stability of the solid electrolyte interface on the graphite anode," J. Power Sources, 268 (2014) 153-162.

24. P. Arora, R. E. White, and M. Doyle, "Capacity fade mechanisms and side reactions in Lithium-ion batteries," J. Electrochem. Soc., 145 (1998) 3647-3667.

25. S.-H. Lee, H.-G. You, K.-S. Han, J. Kim, I.-H. Jung, and J.-H. Song, “A new approach to surface properties of solid electrolyte interphase on a graphite negative electrode," $J$. Power Sources, 247 (2014) 307-313.

26. T. Ohzuku, Y. Iwakoshi, and K. Sawai, "Formation of lithium-graphite intercalation compounds in nonaqueous electrolytes and their application as a negative electrode for a lithium ion (shuttlecock) cell," J. Electrochem. Soc., 140 (9) (1993) 2490-2498.

27. N. Dupré, J.-F. Martin, D. Guyomard, A. Yamada, and R. Kanno, "Characterization of interphases appearing on $\mathrm{LiNi}_{0.5} \mathrm{Mn}_{0.5} \mathrm{O}_{2}$ using ${ }^{7} \mathrm{Li}$ MAS NMR," J. Power Sources, 189 (2009) 557-560.

28. N. Leifer, M. C. Smart, G. K. S. Prakash, L. Gonzalez, L. Sanchez, K. A. Smith, P. Bhalla, C. P. Grey, and S. G. Greenbaum, ${ }^{\circ 13}$ C Solid state NMR suggests unusual breakdown products in SEI formation on Lithium ion electrodes," J. Electrochem. Soc., 158 (5) (2011) A471-A480. 
29. F. M. Wang, D. T. Shieh, J. H. Cheng, and C. R. Yang. "An investigation of the salt dissociation effects on solid electrolyte interface (SEI) formation using linear carbonatebased electrolytes in lithium ion batteries," Solid State Ionics, 180 (40) (2010), 16601666.

30. J. T. Lee, N. Nitta, J. Benson, A. Magasinski, T. F. Fuller, and G. Yushin, “Comparative study of the solid electrolyte interphase on graphite in full Li-ion battery cells using Xray photoelectron spectroscopy, secondary ion mass spectrometry, and electron microscopy," Carbon, 52 (2013) 388-397.

31. H. Ota, Y. Sakata, A. Inoue, and S. Yamaguchi, "Analysis of vinylene carbonate derived SEI layers on graphite anode," J. Electrochem. Soc., 151 (10) (2004) A1659-A1669.

32. M. Herstedt, A. M. Andersson, H. Rensmo, H. Siegbahn, and K. Edstrom, "Characterisation of the SEI formed on natural graphite in PC-based electrolytes," Electrochim. Acta, 49 (27) (2004) 4939-4947

33. V. A. Agubra, J. W. Fergus, R. Fu, and S.-Y. Choe, "Analysis of effects of the state of charge on the formation and growth of the deposit layer on graphite electrode of pouch type lithium ion polymer batteries," J. Power Sources, 270 (2014) 213-220.

34. V. A. Agubra, J. W. Fergus, R. Fu, and S.-Y. Choe, "Analysis of the deposit layer from electrolyte side reaction on the anode of the pouch type lithium ion polymer batteries: The effect of state of charge and charge rate," Electrochim. Acta, 149 (2014), 1-10.

35. K. Edström, M. Herstedt, and D. P. Abraham, “A new look at the solid electrolyte interphase on graphite anodes in Li-ion batteries," J. Power Sources, 153 (2) (2006) 380384.

36. G. V. Zhuang, K. Xu, T. R. Jow, and P. N. Ross, "Study of SEI layer formed on graphite anodes in PC/LiBOB electrolyte using IR spectroscopy," Electrochem. Solid State Lett., 7 (8) (2004) A224-A227. 
37. K. Kwon, F. P. Kong, F. McLarnon, and J. W. Evans, "Characterization of the SEI on a carbon film electrode by combined EQCM and spectroscopic ellipsometry," $J$. Electrochem. Soc., 150 (2) (2003) A229-A233

38. S. Leroy, F. Blanchard, R. Dedryvère, H. Martinez, B. Carré, D. Lemordant, and D. Gonbeau, "Surface film formation on a graphite electrode in Li-ion batteries: AFM and XPS study,” Surf. Interface Anal., 37 (10) (2005) 773-781.

39. M. Broussely, S. Herreyre, P. Biensan, P. Kasztejna, K. Nechev, and R. J. Staniewicz, “Aging mechanism in Li ion cells and calendar life predictions," J. Power Sources, 9798 (2001) 13-21.

40. R. Spotnitz, "Simulation of capacity fade in Lithium-ion batteries," J. Power Sources, 113 (2003) 72-80.

41. P. Ramadass, B. Haran, P. Gomadam, R. White, and B. Popov, "Development of first principles capacity fade model for Li-ion cells," J. Electrochem. Soc., 151 (2) (2004) A196-A203.

42. H. J. Ploehn, P. Ramadass, and R. E. White, "Solvent diffusion model for aging of lithium-ion battery cells," J. Electrochem. Soc., 151 (3) (2004) A456-A462.

43. B. M. L. Rao, R. W. Francis, and H. A. Christopher, "Lithium-aluminum electrode," J. Electrochem. Soc., 124 (10) (1977) 1490-1492.

44. J.-M. Tarascon and M. Armand, "Issues and challenges facing rechargeable lithium batteries," Nature, 414 (2001) 359-367.

45. J. Vetter et al., "Ageing mechanisms in lithium-ion batteries, J. Power Sources, 147 (2005) 269-281.

46. J. Fan and S. Tan, "Studies on charging lithium-ion cells at low temperatures," J. Electrochem. Soc., 153 (6) (2006) A1081-A1092.

47. J.-N. Chazalviel, "Electrochemical aspects of the generation of ramified metallic electrodeposits," Phys. Rev. A, 42 (1990) 7355-7367 
48. P. Arora, M. Doyle, R. E. White, "Mathematical modeling of the lithium deposition overcharge reaction in lithium-ion batteries using carbon-based negative electrodes," $J$. Electrochem. Soc., 146 (10) (1999) 3543-3553.

49. C. Monroe and J. Newman, "Dendrite growth in lithium/polymer systems: A propagation model for liquid electrolytes under galvanostatic conditions," J. Electrochem. Soc., 150 (10) (2003) A1377-A1384.

50. K. Nishikawa, T. Mori, T. Nishida, Y. Fukunaka, and M. Rosso, "Li dendrite growth and Li+ ionic mass transfer phenomenon," J. Electroanal. Chem., 661 (2011) 84-89.

51. R. Akolkar, "Modeling dendrite growth during lithium electrodeposition at sub-ambient temperature," J. Power Sources, 246 (2014) 84-89.

52. A. Jana, D. R. Ely, R. E. García, "Dendrite-separator interactions in lithium-based batteries," J. Power Sources, 275 (2015) 912-921

53. C. T. Love, O. A. Baturina, and K. E. Swider-Lyons, "Observation of lithium dendrites at ambient temperature and below," Electrochem. Soc. Electrochem. Lett., 4 (2) (2015) A24-A27.

54. R. Bhattacharyya, B. Key, H. Chen, A. S. Best, A. F. Hollenkamp, and C. P. Grey, "In situ NMR observation of the formation of metallic lithium microstructures in lithium batteries," Nature Mater., 9 (2010) 504-510.

55. M. Zier, F. Scheiba, S. Oswald, J. Thomas, D. Goers, T. Scherer, M. Klose, H. Ehrenberg, and J. Eckert, "Lithium dendrite and solid electrolyte interphase investigation using $\mathrm{OsO}_{4}, ” J$. Power Sources, 266 (2014) 198-207.

56. X. Zhang, W. Shyy, and A. M. Sastry, "Numerical simulation of intercalation-induced stress in Li-ion battery electrode particles," J. Electrochem. Soc., 154 (2007) A910A916.

57. S. Renganathan, G. Sikha, S. Santhanagopalan, and R. E. White, "Theoretical analysis of stresses in a lithium-ion cell," J. Electrochem. Soc., 157 (2010) A155-A163. 
58. J. Christensen and J. Newman, "Stress generation and fracture in lithium insertion materials,” J. Solid State Electrochem., 10 (2006) 293-319.

59. J. Christensen and J. Newman, "A mathematical model of stress generation and fracture in lithium manganese oxide,” J. Electrochem. Soc., 153 (6) (2006) A1019-A1030.

60. R. Purkayastha and R. McMeeking, "A parameter study of intercalation of lithium into storage particles in a lithium-ion battery," Comput. Mater. Sci., 80 (2013) 2-14.

61. Z. Choi, D. Kramer, and R. Moenig, "Correlation of stress and structural evolution in $\mathrm{Li}_{4} \mathrm{Ti}_{5} \mathrm{O}_{12}$-based electrodes for lithium ion batteries," J. Power Sources, 240 (2013) 245251.

62. A.-C. Walk, M. Huttin, and M. Kamlah, "Comparison of a phase-field model for intercalation induced stresses in electrode particles of lithium ion batteries for small and finite deformation theory," Eur. J. Mech. - A/Solids, 48 (2014) 74-82.

63. S. Bhattacharya, A. R. Riahi, and A. T. Alpas, "A transmission electron microscopy study of crack formation and propagation in electrochemically cycled graphite electrode in lithium-ion cells,” J. Power Sources 196 (20) (2011) 8719-8727.

64. M. Ender, J. Joos, T. Carraro, and E. Ivers-Tiffée, "Three-dimensional reconstruction of a composite cathode for lithium-ion cells," Electrochem. Comm. 13 (2) (2011) 166-168.

65. M. Ender, J. Joos, A. Weber, and E. Ivers-Tiffée, “Anode microstructures from highenergy and high-power lithium-ion cylindrical cells obtained by X-ray nanotomography," J. Power Sources 269 (2014) 912-919.

66. J. W. Fergus, "Recent developments in cathode materials for lithium ion batteries," $J$. Power Sources, 195 (4) (2010) 939-954.

67. K. Padhi, K. S. Nanjundaswamy, and J. B. Goodenough, "Phospho-olivines as positive-electrode materials for rechargeable lithium batteries," J. Electrochem. Soc., 144 (2) (1997) 1188-1194. 
68. J. Xu, Y. Hu, T. Liu, and X. Wu, "Improvement of cycle stability for high-voltage lithium-ion batteries by in-situ growth of SEI film on cathode," Nano Energy, 5 (2014) $67-73$.

69. S. Tan, Z. Zhang, Y. Li, Y. Li, J. Zheng, Z, Zhou, and Y. Yang, "Tris(hexafluoro-isopropyl)phosphate as an SEI-forming additive on improving the electrochemical performance of the $\mathrm{Li}\left[\mathrm{Li}_{0.2} \mathrm{Mn}_{0.56} \mathrm{Ni}_{0.16} \mathrm{Co}_{0.08}\right] \mathrm{O}_{2}$ cathode material," J. Electrochem. Soc., 160 (2) (2013) A285-A292.

70. T. Kawamura, A. Kimura, M. Egashira, S. Okada, and J.-I. Yamaki, "Thermal stability of alkyl carbonate mixed-solvent electrolytes for lithium ion cells," J. Power Sources, 104 (2) (2002) 260-264.

71. W. Kong, H. Li, X. Huang, and L. Chen, "Gas evolution behaviors for several cathode materials in lithium-ion batteries," J. Power Sources, 142 (2005) 285-291.

72. K.-W. Nam, S.-M. Bak, E. Hu, X. Yu, Y. Zhou, X. Wang, L. Wu, Y. Zhu, K.-Y. Chung, and X.-Q. Yang, "Combining in situ synchrotron X-ray diffraction and absorption techniques with transmission electron microscopy to study the origin of thermal instability in overcharged cathode materials for lithium-ion batteries," Adv. Funct. Mater., 23 (8) (2013) 1047-1063.

73. M. Zhao, S. Kariuki, H. D. Dewald, F. R. Lemke, R. J. Staniewicz, E. J. Plichta, and R. A. Marsh, "Electrochemical stability of copper in lithium-ion battery electrolytes," $J$. Electrochem. Soc., 147 (8) (2000) 2874-2879.

74. H. Maleki, and J. N. Howard, "Effects of overdischarge on performance and thermal stability of a Li-ion cell," J. Power Sources, 160 (2006) 1395-1402.

75. J. W. Braithwaite, A. Gonzales, G. Nagasubramanian, S. J. Lucero, D. E. Peebles, J. A. Ohlhausen, and W. R. Cieslak, "Corrosion of lithium-ion battery current collectors," J. Electrochem. Soc., 146 (2) (1999) 448-456. 
76. M. Zhao, H. D. Dewald, R. J. Staniewicz, "Quantitation of the dissolution of batterygrade copper foils in lithium-ion battery electrolytes by flame atomic absorption spectroscopy," Electrochim. Acta, 49 (2004) 683-689.

77. M. Xu and H. D. Dewald, "Controlled-potential electrolysis of copper foil and graphitecoated copper foil in a nonaqueous $1 \mathrm{M} \mathrm{LiPF}_{6}$ in a ternary organic carbonate solvent," Microchem. J., 81 (2005) 225-229.

78. S. S. Zhang andT. R. Jow, "Aluminum corrosion in electrolyte of Li-ion battery," $J$. Power Sources, 109 (2) (2002) 458-464.

79. E. Cho et al., "Corrosion/passivation of aluminum current collector in bis(fluorosulfonyl) imide-based ionic liquid for lithium-ion batteries," Electrochem. Commun., 22 (2012) 13.

80. P. Arora and Z. Zhang, "Battery separators," Chem. Rev., 104 (2004) 4419-4462.

81. C. Peabody and C. B. Arnold, "The role of mechanically induced separator creep in lithium-ion battery capacity fade,” J. Power Sources, 196 (19) (2011) 8147-8153.

82. G. Venugopal, J. Moore, J. Howard, and S. Pendalwar, "Characterization of microporous separators for lithium-ion batteries," J. Power Sources, 77 (1) (1999) 34-41.

83. X. Huang, "Separator technologies for lithium-ion batteries," J. Solid State Electrochem., 15 (2011) 649-662.

84. W. Wu, X. Xiao, X. Huang, and S. Yan, "A multiphysics model for the in situ stress analysis of the separator in a lithium-ion battery cell," Comput. Mater. Sci., 83 (2014) $127-136$.

85. L. Yang, A. Xiao, and B. L. Lucht, "Investigation of solvation in lithium ion battery electrolytes by NMR spectroscopy," J. Mol. Liq., 154 (2-3) (2010) 131-133.

86. H.Yang, G. V. Zhuang, and P. N. Ross Jr., "Thermal stability of LiPF 6 salt and Li-ion battery electrolytes containing LiPF," J. Power Sources 161 (1) (2006) 573-579B. 
87. Scrosati and J. Garche, "Lithium batteries: Status, prospects and future," J. Power Sources, 195 (9) (2010) pp. 2419-2430.

88. G. G. Botte, R. E. White, Z. Zhang, "Thermal stability of $\mathrm{LiPF}_{6}-\mathrm{EC}: \mathrm{EMC}$ electrolyte for lithium ion batteries," J. Power Sources 97-98 (2001) 570-575.

89. J.S. Gnanaraj, E. Zinigrad, L. Asraf, H.E. Gottlieb, M. Sprecher, D. Aurbach, M. Schmidt, "The use of accelerating rate calorimetry (ARC) for the study of the thermal reactions of Li-ion battery electrolyte solutions," J. Power Sources 119-121 (2003) 794798.

90. G.-H. Kim, A. Pesaran, and R. Spotnitz, "A three-dimensional thermal abuse model for lithium-ion cells," J. Power Sources, 170 (2007) 476-489.

91. S. Santhanagopalan, P. Ramadass, and J. Zhang, "Analysis of internal short-circuit in a Lithium-ion cell,” J. Power Sources, 194 (2009) 550-557.

92. T. G. Zavalis, B. Behm, and G. Lindbergh, "Investigation of short-circuit scenarios in a Lithium-ion battery cell," J. Electrochem. Soc., 159 (6) (2012), A848-A859.

93. National Highway Transportation Safety Administration, Chevrolet Volt battery incident overview report, 2012, accessed on 1/11/15 from: http://wwwodi.nhtsa.dot.gov/acms/cs/jaxrs/download/doc/UCM399393/INRP-PE11037-49880.pdf

94. B. Reich and E. B. Hakim, "Environmental factors governing field reliability of plastic transistors and integrated circuits," Reliab. Phys. Symp., (1972) 82-87.

95. E. Bumiller and C. Hillman, "A review of models for time-to-failure due to metallic migration mechanisms," DfR Solutions White Paper, 2012, accessed on 8/22/13 from: http://www.dfrsolutions.com/wp-content/uploads/2012/06/Review-of-Models-for-Timeto-Failure-Due-to-Metallic-Migration-Mechanisms.pdf

96. R. T. Howard, "Electrochemical model for corrosion of conductors on ceramic substrates," IEEE Trans. Compon., Hybrids, Manuf. Technol., 4 (4) (1981) 520-525. 
97. M. Pecht and W. C. Ko, "A corrosion rate equation for microelectronic die metallization," Int. J. Hybrid Microelectron., 13 (2) (1990) 42-51.

98. E. Sahraei, J. Campbell, and T. Wierzbicki, "Modeling and short circuit detection of 18650 Li-ion cells under mechanical abuse conditions,” J. Power Sources, 220 (2012) $360-372$.

99. E. Sahraei, J. Meier, and T. Wierzbicki, "Characterizing and modeling mechanical properties and onset of short circuit for three types of lithium-ion pouch cells," J. Power Sources, 247 (2014) 503-516. 


\section{Table 1 (part 1)}

\begin{tabular}{|c|c|c|c|c|c|c|c|c|}
\hline $\begin{array}{c}\text { Battery } \\
\text { Component }\end{array}$ & $\begin{array}{c}\text { Potential Failure } \\
\operatorname{Mode}(\mathbf{s})\end{array}$ & $\begin{array}{l}\text { Potential Failure } \\
\text { Mechanism(s) }\end{array}$ & $\begin{array}{l}\text { Mechanism } \\
\text { Type }\end{array}$ & Observed Effect & Potential Failure Causes & $\begin{array}{l}\text { Likelihood of } \\
\text { Occurrence }\end{array}$ & $\begin{array}{l}\text { Severity of } \\
\text { Occurrence }\end{array}$ & $\begin{array}{c}\text { Ease of } \\
\text { Detection }\end{array}$ \\
\hline \multirow{4}{*}{$\begin{array}{l}\text { Anode (Active } \\
\text { Material) }\end{array}$} & $\begin{array}{l}\text { Thickening of } \\
\text { solid electrolyte } \\
\text { interphase layer }\end{array}$ & $\begin{array}{l}\text { Chemical reduction } \\
\text { reaction and deposition }\end{array}$ & Wearout & $\begin{array}{l}\text { Increased charge transfer } \\
\text { resistance, reduction of } \\
\text { capacity, reduction of power }\end{array}$ & $\begin{array}{c}\text { Chemical side reactions } \\
\text { between lithium, electrode, and } \\
\text { solvent }\end{array}$ & High & Low & High \\
\hline & Particle fracture & Mechanical stress & Overstress & $\begin{array}{l}\text { Reduction of capacity, } \\
\text { reduction of power }\end{array}$ & Intercalation stress & Moderate & Low & Low \\
\hline & $\begin{array}{l}\text { Reduced electrode } \\
\text { porosity }\end{array}$ & Mechanical degradation & Wearout & $\begin{array}{l}\text { Increased diffusion } \\
\text { resistance, reduction of } \\
\text { capacity, } \\
\text { reduction of power }\end{array}$ & $\begin{array}{c}\text { Dimensional changes in } \\
\text { electrode }\end{array}$ & Moderate & Low & Low \\
\hline & $\begin{array}{l}\text { Lithium plating } \\
\text { and dendrite } \\
\text { growth on anode } \\
\text { surface }\end{array}$ & Chemical reaction & Wearout & $\begin{array}{c}\text { Can cause short circuit if } \\
\text { dendrites puncture separator }\end{array}$ & $\begin{array}{l}\text { Charging the battery at low } \\
\text { temperatures or high rates }\end{array}$ & Low & High & Low \\
\hline $\begin{array}{l}\text { Anode (Current } \\
\text { Collector) }\end{array}$ & $\begin{array}{c}\text { Free copper } \\
\text { particles or copper } \\
\text { plating }\end{array}$ & $\begin{array}{l}\text { Chemical corrosion } \\
\text { reaction and dissolution }\end{array}$ & Wearout & $\begin{array}{l}\text { Increased resistance, } \\
\text { reduction of power, } \\
\text { reduction of current density }\end{array}$ & Overdischarge of the battery & Low & High & Low \\
\hline \multirow{4}{*}{$\begin{array}{l}\text { Cathode (Active } \\
\text { Material) }\end{array}$} & $\begin{array}{l}\text { Thickening of } \\
\text { solid electrolyte } \\
\text { interphase layer }\end{array}$ & $\begin{array}{l}\text { Chemical reduction } \\
\text { reaction and deposition }\end{array}$ & Wearout & $\begin{array}{l}\text { Increased charge transfer } \\
\text { resistance, reduction of } \\
\text { capacity, reduction of power }\end{array}$ & $\begin{array}{c}\text { Chemical side reactions } \\
\text { between lithium, electrode, and } \\
\text { solvent }\end{array}$ & High & Low & High \\
\hline & Particle fracture & Mechanical stress & Overstress & $\begin{array}{l}\text { Reduction of capacity, } \\
\text { reduction of power }\end{array}$ & Intercalation stress & Moderate & Low & Low \\
\hline & $\begin{array}{l}\text { Reduced electrode } \\
\text { porosity }\end{array}$ & Mechanical degradation & Wearout & $\begin{array}{l}\text { Increased diffusion } \\
\text { resistance, reduction of } \\
\text { capacity, } \\
\text { reduction of power }\end{array}$ & $\begin{array}{c}\text { Dimensional changes in } \\
\text { electrode }\end{array}$ & Moderate & Low & Low \\
\hline & $\begin{array}{l}\text { Gas generation } \\
\text { and bloating of } \\
\text { cell casing }\end{array}$ & $\begin{array}{l}\text { Thermally driven } \\
\text { electrode decomposition }\end{array}$ & Overstress & Reduction of capacity & $\begin{array}{c}\text { Overcharge of the battery or } \\
\text { short circuit }\end{array}$ & Low & High & Low \\
\hline $\begin{array}{l}\text { Cathode } \\
\text { (Current } \\
\text { Collector) }\end{array}$ & $\begin{array}{l}\text { Pitting corrosion } \\
\text { of aluminum }\end{array}$ & $\begin{array}{l}\text { Chemical corrosion } \\
\text { reaction }\end{array}$ & Wearout & $\begin{array}{l}\text { Increased resistance, } \\
\text { reduction of power, } \\
\text { reduction of current density }\end{array}$ & Overcharge of the battery & Low & Moderate & Low \\
\hline
\end{tabular}




\section{Table 1(part 2)}

\begin{tabular}{|c|c|c|c|c|c|c|c|c|}
\hline Battery Component & $\begin{array}{c}\text { Potential Failure } \\
\operatorname{Mode}(\mathbf{s})\end{array}$ & $\begin{array}{c}\text { Potential Failure } \\
\text { Mechanism(s) }\end{array}$ & $\begin{array}{c}\text { Mechanism } \\
\text { Type }\end{array}$ & Observed Effect & Potential Failure Causes & $\begin{array}{c}\text { Likelihood of } \\
\text { Occurrence }\end{array}$ & $\begin{array}{l}\text { Severity of } \\
\text { Occurrence } \\
\end{array}$ & $\begin{array}{c}\text { Ease of } \\
\text { Detection }\end{array}$ \\
\hline \multirow[t]{2}{*}{ Separator } & Hole in separator & Mechanical damage & Overstress & $\begin{array}{l}\text { High heat generation due } \\
\text { to joule heating, bloating } \\
\text { of cell casing, drastic } \\
\text { voltage reduction }\end{array}$ & $\begin{array}{c}\text { Dendrite formation, external } \\
\text { crushing of cell }\end{array}$ & Low & High & Moderate \\
\hline & $\begin{array}{c}\text { Closing of separator } \\
\text { pores }\end{array}$ & $\begin{array}{c}\text { Thermally induced melting } \\
\text { of separator }\end{array}$ & Overstress & $\begin{array}{l}\text { Inability to charge or } \\
\text { discharge battery }\end{array}$ & High internal cell temperature & Low & High & High \\
\hline Lithium ions & $\begin{array}{c}\text { Reduction in } \\
\text { lithium ions, } \\
\text { thickening of solid } \\
\text { electrolyte } \\
\text { interphase layer } \\
\end{array}$ & $\begin{array}{l}\text { Electrolyte reduction and } \\
\text { solid product formation }\end{array}$ & Wearout & Reduction of capacity & $\begin{array}{l}\text { Chemical side reactions between } \\
\text { lithium, electrodes, and solvent }\end{array}$ & High & Low & High \\
\hline Electrolyte Salt & $\begin{array}{l}\text { Decrease in lithium } \\
\text { salt concentration }\end{array}$ & $\begin{array}{l}\text { Chemical reduction reaction } \\
\text { and deposition }\end{array}$ & Wearout & $\begin{array}{l}\text { Increased diffusion } \\
\text { resistance }\end{array}$ & $\begin{array}{l}\text { Chemical side reactions between } \\
\text { lithium, electrodes, and solvent }\end{array}$ & High & Low & High \\
\hline \multirow[b]{2}{*}{ Organic Solvents } & $\begin{array}{l}\text { Gas generation and } \\
\text { bloating of cell } \\
\text { casing }\end{array}$ & $\begin{array}{l}\text { Chemical decomposition of } \\
\text { solvent }\end{array}$ & Overstress & $\begin{array}{l}\text { Increased diffusion } \\
\text { resistance, and may lead } \\
\text { to thermal runaway }\end{array}$ & $\begin{array}{l}\text { High external temperature, } \\
\text { overcharging of the cell }\end{array}$ & Low & High & Low \\
\hline & $\begin{array}{l}\text { Thickening of solid } \\
\text { electrolyte } \\
\text { interphase layer }\end{array}$ & $\begin{array}{l}\text { Chemical reduction reaction } \\
\text { and deposition }\end{array}$ & Wearout & $\begin{array}{l}\text { Increased charge transfer } \\
\text { resistance, reduction of } \\
\text { capacity, reduction of } \\
\text { power } \\
\end{array}$ & $\begin{array}{l}\text { Chemical side reactions between } \\
\text { lithium, electrodes, and solvent }\end{array}$ & High & Low & High \\
\hline \multirow[t]{3}{*}{ Terminals } & $\begin{array}{l}\text { External corrosive } \\
\text { path between } \\
\text { positive and } \\
\text { negative leads }\end{array}$ & Chemical corrosion reaction & Wearout & $\begin{array}{l}\text { High heat generation due } \\
\text { to joule heating, bloating } \\
\text { of cell casing, drastic } \\
\text { voltage reduction }\end{array}$ & $\begin{array}{l}\text { Inadvertent shorting of the } \\
\text { terminals }\end{array}$ & Low & High & Moderate \\
\hline & \multirow{2}{*}{ Solder cracking } & Thermal fatigue & \multirow{2}{*}{ Wearout } & \multirow{2}{*}{$\begin{array}{c}\text { Loss of conductivity } \\
\text { between battery and host } \\
\text { device }\end{array}$} & \multirow{2}{*}{ Circuit disconnect } & \multirow{2}{*}{ Low } & \multirow{2}{*}{ Moderate } & \multirow{2}{*}{ High } \\
\hline & & Mechanical vibration fatigue & & & & & & \\
\hline Casing & $\begin{array}{l}\text { Internal short circuit } \\
\text { between anode and } \\
\text { cathode }\end{array}$ & Mechanical stress & Overstress & $\begin{array}{l}\text { High heat generation due } \\
\text { to joule heating, bloating } \\
\text { of cell casing, drastic } \\
\text { voltage reduction }\end{array}$ & External load on cell & Low & High & Moderate \\
\hline
\end{tabular}


Figure 1

Separator

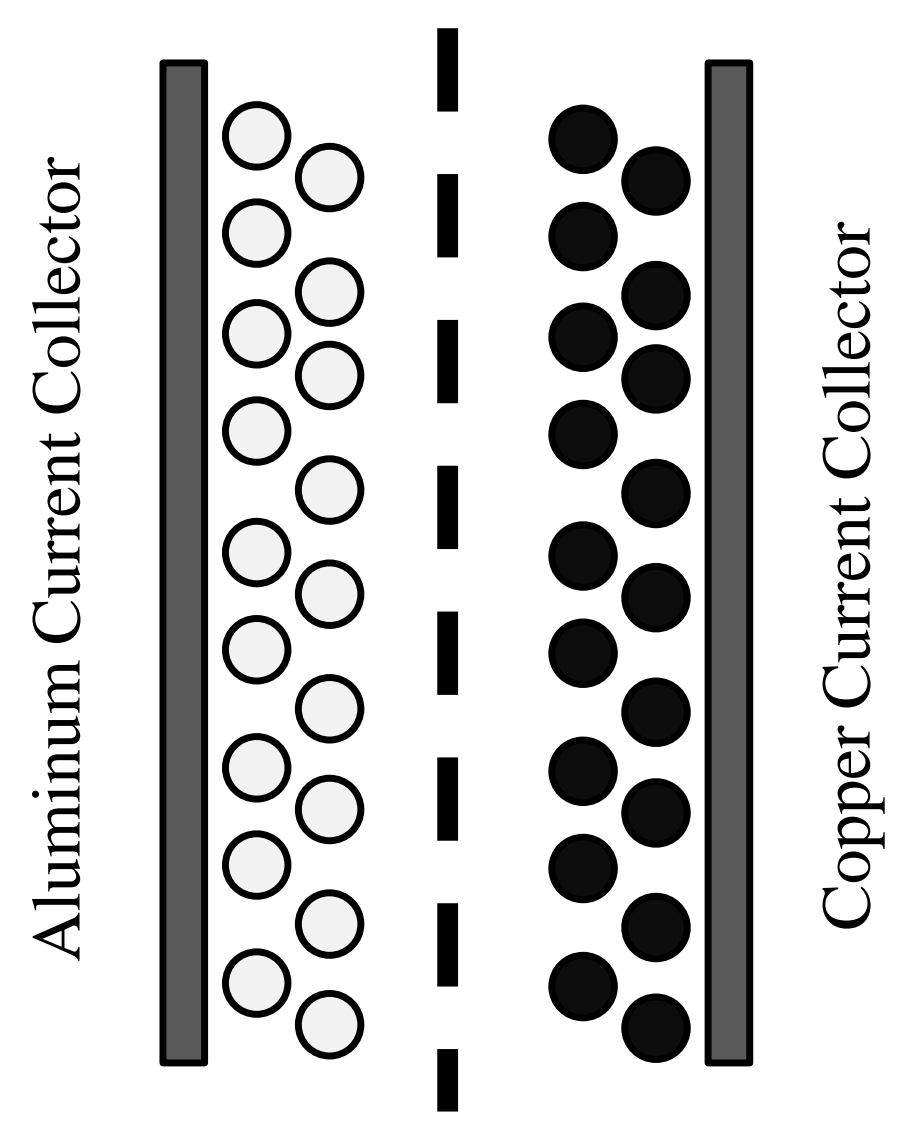

Cathode Anode 